\title{
The concept of LOVE and its conceptualization in modern English romance novels
}

\author{
O. H. Savchuk, N. M. Marchenko
}

\author{
SHEI «Pereiaslav-Khmelnytskyi Hryhory Skovoroda State Pedagogical University» \\ Pereiaslav-Khmelnytskyi, Ukraine \\ Corresponding author.E-mail: helga_savchuk@i.ua,1marchenko_n@ukr.net
}

\begin{abstract}
Paper received 27.01.18; Revised 02.02.18; Accepted for publication 05.02.18.
https://doi.org/10.31174/SEND-Ph2018-151VI44-12

Abstract. The article applies to the theory of conceptual metaphor to give a detailed analysis of how metaphor-based schemata provide the realization of the concept of LOVE in modern romance novels. The results of nominative unit semantic analysis have allowed us to distinguish such topic domains as elements of nature, natural phenomena, and natural geo-complexes which are of primary importance in creating an image of deep, desperate, and long-lasting love. These images are also formed by the conceptual field "love feelings - natural phenomena".
\end{abstract}

Keywords: concept, metaphor, love, images of inanimate and animate nature, language means, conceptual schema.

Introduction. Love constitutes a multifaceted concept, related to almost all aspects of human life, from the instinctive functions of the body to the most volatile manifestations of the spirit. For this reason, love is studied from the perspectives of philosophy, psychology, sociology, anthropology, ethology etc. And they all highlight different aspects or dimensions of this phenomenon, showing its complex character. Among linguistic approaches to the language of love it is cognitive that is of researchers' primary interest.

Cognitive studies, focused on the relationship between language and the mind, attempt to explain the mental processes that underlie the acquisition, storage, production and understanding of speech, how language form and use emerge from conceptualization, the way human experience is perceived and conceptualized [8, p. 11]. Thus, research of an individual's verbalized forms of knowledge as well as the reconstruction of communicants' language picture of the world tend to be a key field in modern linguistic studies.

The figurative language of genre fiction is regarded as one of the most exciting forms of modern language reality where authors vividly depict individual characters, their sensory perceptions and experiences, constructs the whole society's model of the world. Their rich worldview is reflected in/through the system of language images, metaphorical in particular. The later has long been considered to be a device of the poetic imagination and the rhetorical flourish. The scholars view it as characteristic of language alone, a matter of words rather than thought or action suggesting that even our everyday conceptual system is largely metaphorical [6, p. 453-454].

During recent decades, there have been many attempts to reveal the nature of metaphors, the most thoroughgoing treatment of metaphor is found in G. Lakoff and M. Johnson [7]. Here the authors identify the core metaphors that underlie our thinking about a vast array of domains, and argue that the domains are understood only by means of these metaphors [7]. There have been several studies of this issue whose findings not only support this idea but also allow stating that the representational structure that maps knowledge about a conceptual metaphor's vehicle domain onto its topic domain is a metaphor-based schema. They exemplify it by the domain of love which, in their opinion, is often understood through the schema love is a physical force, in which conceptual structures associated with physical forces are mapped onto the domain of ro- mantic feelings, and in the process, influence the way they are understood [3, p. 612].

Like the experience of some love feelings itself, metaphors make connections. We comprehend these experiences and lead our lives via specific conceptual metaphors. They are not simply confined to linguistics, but also have entered into and become spotlight of fields of philosophy, cognitive science, artificial intelligence, psychology, sociology and education. So, it is no surprise that love as well as other related feelings have been imagined, examined, and remembered through a wide variety of figurative comparisons where metaphors are of primary importance. Thus, there is no doubt that the nature of love feelings and, what is more important, their mental representation, analyzed through examining language means that convey meanings and connotations of activities of love within a specific cultural setting, should be studied in terms of metaphors.

Review of Past Research. Current multi-dimensional research on positive feelings in general and love in particular are so vast and varied that reviewing them all is beyond the objectives of this study. At this point, however, it is important to briefly introduce a few major trends in the studies of this feeling relevant to the raised issue in this research along with, at least, general defining of the term "love" and some other closely related notions.

Although feelings, particularly the concept of love as one of the most powerful due to humans' inclination to form bonds with one another through social interactions, have been a subject of some profound research [e.g., 4; 3; 1] which has allowed scholars to define its nature and the most significant features at the intersection of various scientific disciplines, both formal and empiric, scholarly analysis of this issue remains to be of major interest for a number of reasons. First, as A. Wierzbicka states, its emergence in Western folk philosophy constitutes a significant stage in the development of human ideas and human values [10, p. 146]. Along with this, the scholar underlines that «whatever it is thought about the significance of love, it is an illusion to think that it is a universal, natural, or basic human concept» [10, p. 147]. The statement quite naturally leads to understanding of the diversity of existing language means and techniques that writers are bound to use to represent the picture of the world in this perspective. Second, considering different approaches to the description of love, the authors [1, p. 167] state that as this concept is common to many cultures and pictures 
of the world, it is specifically manifested in national and individual consciousness. They argue that in English quite extensive nominative field represents romantic feelings, love in particular including lexical and phraseological units, and representing such cognitive characteristics as inconsistency; irrationality; spontaneity, lack of control; a close relationship with other both positive and negative emotions and feelings; freedom and reciprocity of feelings; a manifestation of selflessness or selfishness; the basis of family relationships; rituality and analogy with the game [1, p. 167]. Moreover, love feelings are thought to be among prototypical emotions which receive the highest prototypicality rating of any emotions [4, p. 426].

Statement of the Objective and Purpose. Despite the diversity of definitions of love feeling, which is believed to be "an attitude held by one person toward another, involving a predisposition to think, feel, and behave in certain ways toward that person" [9, p. 266], and a vast number of its subtypes [e.g., 4, p. 427], we are particularly concerned with the directly verbalized forms of how one character feels about another. Generally, a survey of the literature allows us to define "love" as an expressive and pleasurable feeling from an emotional attraction towards another person which usually implies an expression of one's strong affection and preoccupation with a romantic feeling, unrealistic and idealistic attitudes toward a partner, or one's deep and strong emotional desires to connect with another person intimately or romantically.

Thus, this study aims to apply the achievements of cognitive science and the theory of conceptual metaphor in particular, to give an analysis of how metaphor-based schemata provide the romantic feelings representation in modern romance novels.

Methods and Data. The analyzed data sets are authentic extracts from the romantic novels by I. Gower, D. Macomber, S. Sheldon, and D. Steel.

The first step of the analysis was assigning the target domains. We guided ourselves by the cognitive principles of mapping the world and the theory of conceptual metaphor involving the interpretation of the conceptual part of the image as a certain mental space, structured in different realms of knowledge [5, p. 8-20], and the methodology proposed by the scholars [2, p. 162-163] regarding the identification and description of conceptual metaphors representing images of inanimate nature. Thus, all metaphorical models in the studied novels correspond to the target domains of images of animate and inanimate nature which form specific frames of knowledge in a recipient's consciousness.

Presentation of the Results. The basis for the selection of these topic domains, which store knowledge and form nodes of frame, classified according to the source [2, p. 164], and the description of their content is the result of semantic analysis of nominative units used for naming both animate and inanimate objects. Mostly these are lexemes and phrases that mark:

1) animate objects domain mostly represented by images of humans and their activities, states, and experiences - food, parts of the body, diseases, physical movements, behavioral patterns etc.;

2) inanimate objects domain that includes elements of nature - water, fire, land, air etc.; natural phenomena storm, whirlpool, wind, flame, mist, dew, sun, moon, brightness and the like; natural geocomplexes - river, ocean, sea, desert, waves, sky etc.

The results of the analysis have shown that the basis for metaphorical images of love feelings is the conceptual schema PERSON'S EMOTIONAL STATE IS A TYPE OF HUMAN ACTIVITIES, LIKES, and BEHAVIORAL PATTERNS which the author develops by involving a detailed description of related phenomena. The manifestation of a love feeling is achieved by the metaphorical schema LOVE IS A PHYSICAL MOVEMENT, e.g., Elizabeth felt a sudden, urgent impulse of love, she wanted to see him, to tell him her decision about the company [3, p. 229].

Quite similarly, we may see the conceptualization of a strong feeling within the following schema LOVE FOR A PERSON IS A HUMAN SICKNESS. The example illustrates the association of the feeling with a disease, e.g., She was going to join him the villa in Sardinia for Christmas, and as the time drew nearer, the waiting became unbearable. She was sick with excitement [3, p. 134].

The following example Once the phone rang, and her heart leaped and she reached for it, thinking, It's Sam! [3, p. 100], demonstrates personification of the heart that can leap as a human when a person experiences a love feeling, which introduces the schema ROMANTIC FEELING OF LOVE IS A HUMAN HEART.

We have also established that in some cases a deep feeling is represented by image of people in love behaving as in the war. The following example illustrates how the lexical meaning of the verb to conquer facilitates the realization of the textual concept FEELING IS WAR, for instance, Donatella conquered him, and she was his master since then [3, p. 57]. Along with this, the next passage instantiates the association of romantic feeling with the source domain DEEP FEELING IS FOOD / EATING / HUNGER and the like, i.e. phenomena that are of vital importance for a human, which can be seen in the following: Rhys starved for love [3, p. 28]. Here it should be mentioned that the same deep emotional state can also be associated with such negative source domain as death, for instance, Anna turned to Walther and his eyes were filled with tears. And she could have died right then of happiness [3, p. 40].

The analysis of the frequency distribution of different images of nature, which aim to activate the writer's / reader's knowledge of love feelings, showed that a great mass of them belongs to the topic domain of natural elements and geo-complexes, mostly to the image of water. It is noteworthy that this object of associations can be a generalized picture of water as well as its concrete manifestations like sea, tide, river etc. This image facilitates a formation of conceptual schemata. They include: BURNING LOVE IS A ROUGH SEA / A DEEP SEA; SUFFERING FROM LOVE IS DEBRIS FROM THE SEA; FALLING IN LOVE IS A TIDE; LOVE EXCITEMENT IS A WAVE. These ways of romantic feelings conceptualization are transformed highly conventional universal metaphorical schemata LOVE IS AN OCEAN; PASSION IS A DEEP BLUE SEA; TO LOVE IS TO DROWN IN THE RIVER OF EMOTIONS. As the following example demonstrates, Rachel comprehends her love experiences by imagining a warm flowing river: They held hands, and every now and then he'd lean forward to kiss the side of her face. Rachel's eyes drifted shut as a river of aware- 
ness flowed through her [2, p. 153]. Similarly, another passage instantiates the association of love feeling with water: He kissed her then, long and hard, and they clung to each other like two people drowning [5, p. 192].

Among some other notable instances of images of love feeling represented by the conceptual field of geocomplexes that extrapolates the deepness of feeling is the metaphorical schema DEEP, TRUE FEELING IS ENDLESS ROAD. This is quite evident from the following utterance: She could not envisage living anywhere else in the world, yet on the heels of that thought was the knowledge that she would follow Brandon to the ends of the earth if he only asked her [1, p. 351].

Other images of elements of nature frequently used in the studied romance novels are mainly universal stereotypes embodied in such metaphorical schemata as LOVE IS RAY OF SUNSHINE; OBSESSIVE FEELING OF LOVE IS FIRE / BLAZE; TENDER FEELING OF LOVE IS AIR / SUN; LOVE EXPERIENCES IS WIND / WHIRLPOOL. Their role in organizing conceptual knowledge can be seen in the following example where Mali Richardson's peaceful love feeling is conveyed by involving a conceptual structure associated with a light wind: The fragrant breeze drifted towards her, heavy with the scent of roses, and she felt a deep sense of peace [1, p. 36].

Metaphorical images, besides elements of nature and natural geo-complexes, are also formed on the basis of the conceptual field FEELINGS OF ROMANTIC LOVE ARE NATURAL PHENOMENA, brought to the process of representation by detailed descriptions of a specific natural phenomenon. These are particularly relevant to metaphors used to convey unpleasant feelings related to love experiences. They underlie the following metaphorical schemata: ANXIETY CAUSED BY LOVE IS LIGHTNING / WHIRLPOOL; FAILED LOVE IS STORM; PAINFUL FEELING OF LOVE IS A FIERCE FLAME. The example below illustrates the intensification of Mary's hopeless state as an image provided by the use of the mentioned above schema: Like a shaft of lightning she was tinglingly aware that she was not meant for marriage and children [1, p. 224].

Language means that underlie the core of the studied feelings include lexical units that convey a metaphorical image giving an idea of the world in the fictional work. These are frequently used verbs which both express the content and conduce to the concept representation, for example, to stir her from, to fill her with, to feel a deep sense of, feel as though etc. Lexical repetitions, enumeration in particular, in some cases accompanied by syntactical repetition play a similar role. This can be seen in the following: Their children, their mates, their memories, their loves. And yet none of it seemed to matter as he kissed her with all the passion that had been pent up over the years and had been long forgotten [5, p. 169]. They also include phrases with the component love in which the other component often acts as a metaphorical epithet, for instance, deep, cruel, burning love; predicative parameters that mark a manner of action (really, absolutely), purpose (to build the future), time and space (over the years, now and then, all around, forever) and the like.
Another passage, on the one hand, illustrates a metaphorical schemata DESPERATE LOVE IS MIST as a part of the mentioned above conceptual field natural phenomena, and, on the other hand, the interaction of lexical (a modal verb and an adverb that convey impossibility and desperation) and syntactical means (parallelism and enumeration) used to objectify the character's feeling: $\underline{\mathrm{He}}$ was back to real life, to the things that mattered to him, his wife, his sons, his business. And somewhere in the distance, receding into the mists, was the woman he had found but could never have, woman he was so desperately in love with [5, p. 194].

Also, the analyzed examples were divided, according to the level of the emotional excitement they express, into 1) increase in emotional tension, 2) emotionally stable state, and 3) decrease in emotional tension which allowed us to trace interdependence between the directions of an emotional state the writer aims to convey and a type of conceptual schema involved in this process.

The results of the analysis prove that an indispensable constituent of the phrases conveying an increase in emotional tension is natural phenomena i.e. whirlpool, wind, and flame. In the following example the state of anxiety and excitement, chiefly raised by her feeling of love, is materialized with the verb to whirl. The image of energetic movement gradually comes down to give way to expectations achieved by a metaphor: Her thoughts whirled as she stood in the bustle of the market square and hope blossomed within her $[1$, p. 226]. It is also noteworthy that this type is often maintained by a mixture of the constituents of natural geo-complexes. As is obvious from the following passage, a contrast between calmness of the sky and roughness of the sea facilitates to create an image of how deep the heroine's feeling is: He smiled and Mary's heart seemed to lift; she felt as though she were floating high on a billowing cloud or sinking in the depths of the foaming sea. It was a strange sensation and she was not sure it was one she liked [1, p. 72].

The second type is mainly actualized by the use of such elements of nature as fire, land, air, and water, e.g., 'And what if I don't want to talk to you?' she said, but her voice was trembling. She was as keen for a tumble as he was, Brandon thought in triumph and his entire body seemed bathed in heat [1, p. 242].

Quite significant in the distribution of the decrease in emotional tension is natural geo-complexes. For instance, the following example demonstrates an image of the rough sea to play a special role in organizing conceptual knowledge about Paige's feeling: Paige felt a surge of excitement [4, p. 235].

The Conclusion. Images of both animate and inanimate objects, mostly lexical units are widely used to mark humans and their activities, states, and experiences as well as elements of nature, and natural phenomena, play an important role in the textual representation of a love feeling. Metaphorical constructions and their dynamic use along with lexical and grammatical, and stylistic language means allow the author, on the level of textual narration, to convey feelings related to romantic experiences and an image of deep, desperate, and long-lasting love.

\section{REFERENCES}

1. Демина Е.А. Лингвистическая репрезентация концепта «любовь» в английском языке / Е.А. Демина, Н.В. Кузне-

цова // Вестник Нижегородского университета им. Н.И. Лобачевского, 2011. - Серия : Филология. - № 6 (2). - С. 
$167-168$.

2. Demina E.A. Linguistic representation of the concept "LOVE" in the English language / E.A. Demina, N.V. Kuznetsova // Vestnik of Nizhegorodsky N.I. Lobachevskiy University, 2011. - Series : Philology. - № 6 (2). - P. 167-168.

3. Морякіна I.А. Образи неживої природи у мовній картині світу англійців (на матеріалі романів форсайтівського циклу Дж. Госуорсі) / Морякіна І.А., Яремко Д.П. // Мова, культура й освіта в сучасному світі : Збірник наукових праць до 90-річчя доктора філологічних наук, професора Романовського О.К. / Відп. ред. Стишов О.А. - К. : Вид. центр КНЛУ, 2008. - С. 162-167.

4. Moriakina I.A. Images of Inanimate Nature in Language Picture of the World of British (Based on The Forsyte Saga Novels by J. Galsworthy) / Moriakina I.A., Yaremko D.P. // Language, Culture and Education in Modern World : Collection of Research Papers Dedicated to 90th Anniversary of Philology Doctor, Professor Romanovskyi O.K. / ed. by Styshov O.A. - K. : Vyd. tsentr KNLU, 2008. - P. 162-167.

5. Allbritton D.W. Metaphor-Based Schemas and Text Representations : Making Connections Trough Conceptual Metaphors / David W. Allbritton, Gail McKoon, Richard J. Gerrig // Journal of Experimental Psychology : Learning, Memory, and Cognition. - 1995. - Vol. 21. - No. 3. - P. 612-625.
6. Fehr B. The Concept of Love Viewed from a Prototype Perspective / Beverley Fehr, James A. Russell // Journal of Personality and Social Psychology. - 1991. - Vol. 60. - No. 3. P. 425-438.

7. Kintsch W. A. The Role of Knowledge in Discourse Comprehension : A Construction-Integration Model / Walter A. Kintsch // Cognitive Modeling / edited by Thad A. Polka and Colleen M. Seifert. - Cambridge, Massachusetts, London : The MIT Press, 2002. - P. 5-48.

8. Lakoff G. Conceptual Metaphor in Everyday Language / George Lakoff, Mark Johnson // The Journal of Philosophy. 1980. -Vol. 77. - Issue 8. - P. 453-486.

9. Lakoff G. Metaphors We Live By / George Lakoff, Mark Johnson. - Chicago : University of Chicago Press, 1980. $256 \mathrm{p}$.

10. Ponterotto D. Studies in Conceptual Metaphor Theory / Diane Ponterotto. - Roma : Aracne, 2014. - 254 p.

11. Rubin Z. Measurement of Romantic Love / Zick Rubin // Journal of Personality and Social Psychology. - 1970. - Vol. 16. - No. 2. - P. 265-273.

12. Wierzbicka A. Semantics, Culture, and Cognition : Universal Human Concepts in Culture-Specific Configurations Department of Linguistics / Anna Wierzbicka. - Oxford : Oxford University Press, 1992. - $496 \mathrm{p}$.

\section{SOURCES OF ILLUSTRATIVE MATERIALS}

1. Gower I. Proud Mary / Iris Gower. - London : Corgi Books, 1984. $-400 \mathrm{p}$.

2. Macomber D. 92 Pacific Boulevard / Debbie Macomber. Ontario : Mira Books, 2009. - 384 p.

3. Sheldon S. Bloodline / Sidney Sheldon. - New York : Time

Warner Trade Publishing, 1988. - 460 p.

4. Sheldon S. Nothing Lasts Forever / Sidney Sheldon. - New York : Warner Books, 1995. - $384 \mathrm{p}$.

5. Steel D. Five Days in Paris / Danielle Steel. - London : Corgi Books, 1995. - 349 p.

\section{Концепт ЛЮБОВЬ и способы его концептуализации в современном любовном английском романе} О. Г. Савчук, Н. Н. Марченко

Аннотация. Исследование позволило определить типичные метафорические модели развертывания концепта, а также рассмотреть концептообразующую роль языковых средств реализации ментальных образов любовных переживаний свойственных современному любовному англоязычному роману. Результаты семантического анализа номинативных единиц позволил выявить такие домены природные стихии, явления и геокомплексы, которые играют ключевую роль в создании образа глубокой, отчаянной, длительной любви. Создание этих образов также достигается концептуальным полем “любовные переживания - явления природы".

Ключевые слова: концепт, метафора, любовь, образы живой и неживой природы, языковые средства, концептуальная схема. 